\title{
DETERMINING FUTURE PRECIPITATION PROBABILITY FOR KAHRAMANMARAS CITY USING MARKOV CHAIN APPROACH
}

\author{
Mahmut REİS ${ }^{1}$, , Hurem DUTAL ${ }^{1}$, Zeynep KAYRAK ${ }^{1}$ \\ ${ }^{1}$ Department of Forest Engineering, Faculty of Forestry, Kahramanmaras Sutcu Imam University, \\ Kahramanmaras
}

*Corresponding author: mreis@ksu.edu.tr

\section{ARTICLE INFO}

Research Article

Received 14 March 2017

Received in revised form 28 April 2017

Accepted 29 April 2017

\begin{abstract}
Precipitation is unique source meeting water need of all ecosystems in the world. It is the irreplaceable element of the organism life. Turkey, particularly its Mediterranean region, ranks among the regions expected precipitation changes due to climate change. Kahramanmaras is located in Mediterranean region where is expected to experience the effects of the climate change at the very most. Since Kahramanmaras has the largest water reserve in Turkey, it is acknowledged as a rational way that alterations in the area should be watched consistently and future plans should be made in the light of a set of prediction models. In this study, it is aimed to predict future precipitation probability for Kahramanmaras city using Markov chain model. For this purpose, 44 years precipitation data including 1970-2014 period belonging to Kahramanmaras precipitation station has been used. Precipitation data has been classified by taking SPI (Standardized Precipitation Index) criterions into consideration. In order to test the model accuracy, observed value in 2014 has been compared with predictions of the model for 2014. Then the model is run for 2015, 2016, 2017, 2018, 2019 and 2020 years. When results have been examined, negligible differences have been seen among predictions value for these years. Thus the results of these 6 years are submitted as a single vector. According to this, predicted precipitation amounts and their probability of occurrences are $1079 \mathrm{~mm}$ and above with 7\%, 990-1078 $\mathrm{mm}$ with 5\%, 545-900 mm with $74 \%, 456-544 \mathrm{~mm}$ with $12 \%$ and $367-455 \mathrm{~mm}$ with $2 \%$ for $2015,2016,2017,2018$, 2019 and 2020 respectively. In addition to this, precipitation amounts are not expected to occur $901-989 \mathrm{~mm}$ and $366 \mathrm{~mm}$ and below for all these years in Kahramanmaras.
\end{abstract}

Keywords: Markov chain model, precipitation prediction, climate change 


\title{
KAHRAMANMARAŞ İLİ İÇIN GELECEĞE YÖNELIK YAĞIŞ \\ OLASILIKLARININ MARKOV ZINCIRLERİ YAKLAŞIMIYLA BELIIRLENMESI
}

\author{
ESER BILGISI \\ Araştırma Makalesi \\ Gelis 14 Mart 2017 \\ Düzeltmelerin Gelişi 28 Nisan 2017 \\ Kabul 29 Nisan 2017
}

ÖZET: Yağışlar dünyadaki tüm ekosistemlerin su ihtiyacını karşılayan yegâne kaynaktır. Canlı yaşamının vazgeçilmez bir ögesidir. Türkiye başta Akdeniz Bölgesi olmak üzere iklim değişikliği nedeniyle yağış değişikliklerinin beklendiği alanlar arasındadır. Kahramanmaraş iklim değişikliğinden en fazla etkilenmesi beklenen Akdeniz Bölgesi' nde yer almaktadır. Türkiye' nin en büyük su rezervine sahip olması nedeniyle bölgede yaşanan değişimin sürekli olarak takip edilmesi ve geleceğe yönelik planların bir takım tahmin modelleri 1şı̆̆ında yapılması akılcı bir yol olarak görülmektedir. Bu çalışmada, Kahramanmaraş ili için geleceğe yönelik yağış olasılıklarının Markov zincirleri modeli kullanılarak tahmin edilmesi amaçlanmıştır. Kahramanmaraş yağış istasyonuna ait 1970-2014 periyodunu kapsayan 44 yıllık yağış verisi kullanılmıştır. Yağış verileri SYİ (Standardize edilmiş Yağış İndeksi) kriterlerine göre sınıflandırılmıştır. Modelin doğruluğunun test edilmesi amacıyla 2014 yılında gözlenen değer ile modelin 2014 yılı için tahmin değerleri karşılaştırılmıştır. Ardından model 2015, 2016, 2017, 2018, 2019 ve 2020 yılları için çalıştırılmıştır. Elde sonuçlara bakıldığında bu yıllar arasındaki tahmin değerlerinin çok küçük farklılıklar gösterdiği görülmüştür. Bu nedenle bu 6 yılın sonuçları tek bir vektör olarak gösterilmiştir. Buna göre Kahramanmaraş’ ta 2015, 2016, 2017, 2018, 2019 ve 2020 yıllarında beklenen yağış miktarları ve gerçekleşme olasılıkları \%7 olasılıkla $1079 \mathrm{~mm}$ ve üzeri, $\% 5$ olasılıkla 990-1078 mm, \%74 olasilıkla $545-900 \mathrm{~mm}, \% 12$ olasilıkla $456-544 \mathrm{~mm}$ ve $\% 2$ olasilıkla $367-455 \mathrm{~mm}$ şeklindedir. Bununla birlikte Kahramanmaraş' ta 901-989 mm arasında ve 366 mm ve altında yağışların oluşması beklenmemektedir.

Anahtar Kelimeler: Markov zinciri modeli, yağış tahmini, iklim değişikliği

\section{INTRODUCTION}

Precipitation is the unique source of fresh, use and irrigation water which are necessary for living life. Thus, changes that take place precipitation pattern affect all ecosystems. Turkey, especially its Mediterranean region, is among areas where is expected to experience effects of climate changes. According to various climate models, it is forecasted to decrease in annual total precipitation, especially winter session at the region that covers East Mediterranean Basin and Turkey (Turkes, 1999). Conventionally, decrease in precipitations is thought as beginning of drought. This causes to decline in reservoir and stream flows (Zamani et al., 2013).

In order to escape damages, with minimum loss, resulting from precipitation changes, making prudential plans in the light of several estimates is seen as the most rationalist way. In this context, demands for studies on precipitation model building increase at the present time. These studies have great important not only for data production purpose but also for water 
resources management, hydrology and agricultural sector (Yusuf et al., 2014). Because information about the probability of occurrence of the precipitation for future can be used to make decisions relating to agricultural production planning and management and water management, it can decrease risks originating weather condition uncertainty (Dash, 2012).

The analysis of rainfall records for long periods provides information about rainfall patterns and variability (Lazaro et al., 2001; Selvi, \& Selvaraj, 2011). Several models are used to analyze precipitation data which represent one of the meteorological phenomena the most difficult to analyze because of their high spatio-temporal variability (Amaud, 1985). Artificial neural network which is a black box model, multiple linear regression and ARMA (AutoRegresif Moving Average) are examples for models used for prediction. But, the most widely used technique is the one based on the models of Markov (N'guessan B1 et al., 2014; Ameur, \& Haddad, 2007). The Markov chain models have two advantages:

(1) Predictions are ready for use immediately after the observations are done, because predictors use only the local information on the weather and (2) they need minimal computation after the climatological data have been processed (Cazacioc, \& Cipu, 2004).

In Markov chain model, dependence state of any variable on previous variable(s) number determine degree of model. For example, in annual precipitation data prediction with first order Markov chain, variables depend on the previous one variable while, in second order Markov chain variables depend on the previous two variables. Similarly, in third order Markov chain, depend on the previous three variables. In Markov chain model, as model degree increases, data number used calculations decrease and error margin in calculations increases (Kocak, \& Sen, 1998). When literature is investigated, it is seen that most researcher use first order Markov chain. For example, Srikanthan, \& Mohan (1984) used first order Markov chain in order to generate annual precipitation data and recommended this model for forecasts. In Italy Kottegoda et al. (2004) reported that first order Markov chain predictions are in compliance observed data. In addition to these studies, Dash (2012), Barkotulla (2010) and Selvi, \& Selvaraj (2011) used first order chain model in their scientific studies.

Classifying precipitation falling in certain area at different time is important to determine accurately future precipitation probability. SPI method developed by Mckee et al. (1993) and used commonly for determining and monitoring drought is quite suitable for classifying precipitation in the world (Ozgurel, \& K1lic, 2003).

Potential effects of climate change on water resource, taking non-uniform distribution of precipitation on earth under current climate conditions and drought tendency into account, become very significant. For example, according to some climate models depending on greenhouse gas emission, climate change will raise water shortage in arid and semi-arid regions in the world (Turkes, 2011). Kahramanmaras located in Mediterranean region of Turkey where is expected to be influenced climate change with global warming.

Turkes (2011), reported to be expected important changes such as hydrologic cycle, melting land and sea ice, decrease in area of snow and ice cover, increase in sea levels, replacement in climate zones, occurring more severely and frequently heat wave, taking place extreme precipitation and overflow in some region, and increase in epidemics depending on extreme temperature due to extreme and more frequent drought events in some region affecting directly socio-economic sectors, ecosystems and human life. 
World average temperature increase was $0.78^{\circ} \mathrm{C}$ in $1901-2012$ period (IPCC, 2014) while, in Kahramanmaras, average temperature increase was $1.03{ }^{\circ} \mathrm{C}$ in $1975-2005$ with the effect of global warming (Cosun, \& Karabulut, 2009). This change observed in Kahramanmaras which has the largest water reservoir in Turkey necessitates studies on investigating future precipitation behavior.

In this study, it is aimed to determine possible annual precipitation amount and probability of occurrence of these precipitation amounts in future using Markov chain approach for Kahramanmaras city.

\section{MATERIAL AND METHOD}

Kahramanmaras whose great part occupies in northeast of the mediterranean region located in transition area which is betwen mediterranean climate and continental climate (Figure 1). But mediterranean climate is more dominant than the other in the city (Korkmaz, 2001). The study area reflects certain characteristics of Mediterranean climate with average annual precipitation of slightly over $700 \mathrm{~mm}$, and precipitation is usually seen in winter and spring seasons in the region. The average annual temperatures is $16.7{ }^{\circ} \mathrm{C}$, while maximum and minimum temperatures are $45.2{ }^{\circ} \mathrm{C}$ (July) and $-9.6{ }^{\circ} \mathrm{C}$ (February), respectively (DMİ, 2010). Kahramanmaras has (C2 B'3 s2 b'3) sub-humid, mesothermal with third degree, large summer water deficiency and near maritime condition climate type according to Thornthwaite climate classification. In the study area, forest ecosystem, bare areas, shrubs areas, grasslands and agricultural systems (fallowing and plantation) exist dominantly.

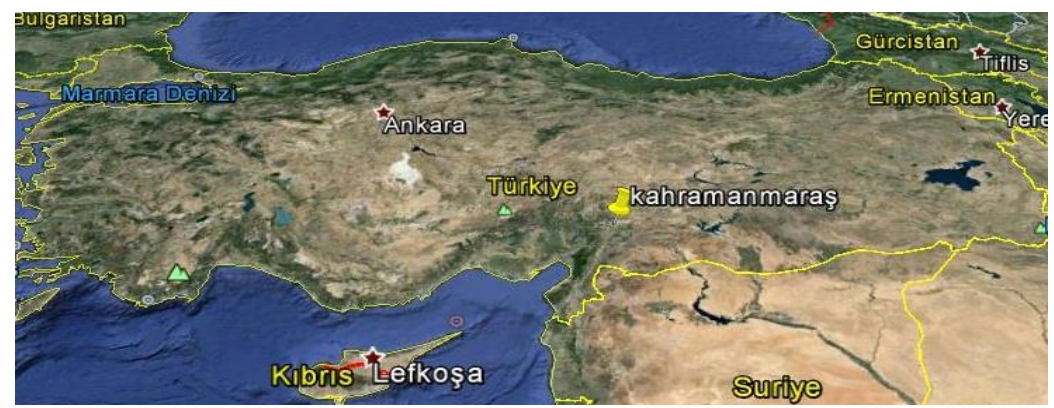

Figure 1. Location of Study Area on Satellite Image

In this study, it is benefited from long term data of the Kahramanmaras precipitation station. Total annual precipitation data of the station belonging to 1970-2014 period is used.

In present study, it is aimed to establish Markov chain model on the purpose of predicting prudential precipitation probabilities. In first level, total annual precipitation falling the study area have been classified to set the model. Classification process is made according to criteria of SPI method developed by McKee et al. (1993). In order to calculate SPI, arithmetic average and standard deviation of precipitation series are needed. SPI $\left(\mathrm{X}_{\mathrm{i}}\right)$, for any $\mathrm{X}_{1}$, $\mathrm{X}_{2}, \ldots ., \mathrm{X}_{\mathrm{n}}$ precipitation time series, is obtained with Eqs. (1) below.

$$
X_{i}=\left(X_{i-X)} / S_{x}\right.
$$

Where; $X$ is average value of time series and $S_{x}$ is standard deviation of time series (Oguzturk, $\&$ Y 1ldiz, 2014). SPI values are classified according to table 1. 
Table 1: Standardized Precipitation Index (SPI) Value Ranges and Corresponding Symbols in Markov Chain Model

\begin{tabular}{|l|c|c|}
\hline \multicolumn{1}{|c|}{ Spi values } & Classification & Symbol \\
\hline 2 and above & Extreme humid & $\mathrm{S}_{1}$ \\
\hline $1.50-1.99$ & Very humid & $\mathrm{S}_{2}$ \\
\hline $1.00-1.49$ & Moderate humid & $\mathrm{S}_{3}$ \\
\hline$(-0.99)-0.99$ & Near normal & $\mathrm{S}_{4}$ \\
\hline$(-1.00)-(-1.49)$ & Moderate dry & $\mathrm{S}_{5}$ \\
\hline$(-1.50)-(-1.99)$ & Very dry & $\mathrm{S}_{6}$ \\
\hline-2.00 and below & Extreme dry & $\mathrm{S}_{7}$ \\
\hline
\end{tabular}

Each class in SPI method is matched with a $\mathrm{S}_{\mathrm{j}}\left(\mathrm{S}_{1}, \mathrm{~S}_{2}, \ldots \mathrm{S}_{\mathrm{n}}\right)$ symbol in Markov chain model. Then, total annual precipitaion amounts belonging to 1970-2014 period is classified according to SPI system and periodically arrayed. P, transition probabilities in Markov model are generated with the help of these data. General structure of transition probability matrix is shown in Figure 2.

Figure 2. General Structure (Winston, 2004).

Initial vector describes present

$$
\begin{array}{lll}
\mathrm{P}_{11} & \mathrm{P}_{12} & \ldots \ldots \ldots \\
\mathrm{P}_{21} & \mathrm{P}_{22} & \ldots \ldots \ldots \\
\ldots & \ldots & \\
\ldots & \ldots & \\
\ldots & \ldots & \\
\ldots & \ldots & \\
\mathrm{P}_{\mathrm{s} 1} & \mathrm{P}_{\mathrm{s} 2} & \ldots \ldots \ldots
\end{array}
$$$$
\begin{gathered}
\mathrm{P}_{1 \mathrm{~s}} \\
\mathrm{P}_{2 \mathrm{~s}} \\
\ldots \\
\ldots \\
\ldots \\
\ldots \\
\mathrm{P}_{\mathrm{ss}}
\end{gathered}
$$

of Transition Matrix

state of system. In other words, it expresses when system is at $t=0$, $i$ state probability of system, $P(X=i)=q$, is and is shown as $\mathrm{q}=\left|\mathrm{q}_{1} \mathrm{q}_{2} \ldots \mathrm{q}_{\mathrm{s}}\right|$ (Austin, \& Burns, 1985). According to that, initial probability vector $\mathrm{V}^{\mathrm{o}}$ is determined for 44 years precipitation series by taking probability of incident of each $S_{j}$ state into account.

$$
\mathrm{P}\left\{\mathrm{X}_{\mathrm{n}}=\mathrm{j}\right\}=\sum_{i=0}^{s} q P_{i j}^{(n)}
$$

If initial states are not known in Markov chain, initial probability vector $\mathrm{q}_{=}=\left|\mathrm{q}_{1} \mathrm{q}_{2} \ldots \mathrm{q}_{\mathrm{s}}\right|$ which show distribution of initial states can be used instead of initial states (Taylor, \& Karlin, 1984). By using that vector and transition matrix, $n$ step transition probabilities of chain can 
be found. Thus, distribution of states in system after $n$ period can be obtained by the help of Eqs. (2) (Akyurt, 2011).

Finally, to test model accuracy is highly important in term of using model. For this, observed value in 2014 compared with values in 2014 predicted by using model.

\section{RESULTS AND DISCUSSION}

The total annual precipitation that occurred during the period 1970-2013 of Kahramanmaras city is classified according to SPI system and then SJ state corresponding to each year in Markov chain model is shown in the table 2. S3 and S7 states are not seen during 44-year period in Kahramanmaras. The most observed situation in this period is "near-normal state" symbolised with S4.

Table 2. Total Annual Precipitation Amounts, Values in SPI and Corresponding Symbols in Markov Chain Model of Kahramanmaras City

\begin{tabular}{|c|c|c|c|c|c|}
\hline Year & Index value & Symbol $\left(\mathbf{S}_{\mathbf{J}}\right)$ & Year & Index value & Symbol $\left.\mathbf{( S}_{\mathbf{J}}\right)$ \\
\hline 1970 & $-0,78$ & $\mathrm{~s} 4$ & 1992 & $-0,58$ & $\mathrm{~s} 4$ \\
\hline 1971 & $-1,12$ & $\mathrm{~s} 5$ & 1993 & $-0,82$ & $\mathrm{~s} 4$ \\
\hline 1972 & $-1,22$ & $\mathrm{~s} 5$ & 1994 & 0,43 & $\mathrm{~s} 4$ \\
\hline 1973 & $-1,43$ & $\mathrm{~s} 5$ & 1995 & 0,12 & $\mathrm{~s} 4$ \\
\hline 1974 & $-0,34$ & $\mathrm{~s} 4$ & 1996 & 2,50 & $\mathrm{~s} 1$ \\
\hline 1975 & 0,03 & $\mathrm{~s} 4$ & 1997 & $-0,12$ & $\mathrm{~s} 4$ \\
\hline 1976 & 2,01 & $\mathrm{~s} 1$ & 1998 & 0,86 & $\mathrm{~s} 4$ \\
\hline 1977 & $-0,86$ & $\mathrm{~s} 4$ & 1999 & $-1,57$ & $\mathrm{~s} 6$ \\
\hline 1978 & 0,34 & $\mathrm{~s} 4$ & 2000 & $-0,24$ & $\mathrm{~s} 4$ \\
\hline 1979 & $-0,83$ & $\mathrm{~s} 4$ & 2001 & $-0,25$ & $\mathrm{~s} 4$ \\
\hline 1980 & 0,14 & $\mathrm{~s} 4$ & 2002 & $-0,65$ & $\mathrm{~s} 4$ \\
\hline 1981 & 0,93 & $\mathrm{~s} 4$ & 2003 & 0,76 & $\mathrm{~s} 4$ \\
\hline 1982 & $-1,36$ & $\mathrm{~s} 5$ & 2004 & $-0,01$ & $\mathrm{~s} 4$ \\
\hline 1983 & $-0,40$ & $\mathrm{~s} 4$ & 2005 & $-0,45$ & $\mathrm{~s} 4$ \\
\hline 1984 & $-0,56$ & $\mathrm{~s} 4$ & 2006 & $-0,39$ & $\mathrm{~s} 4$ \\
\hline 1985 & $-0,43$ & $\mathrm{~s} 4$ & 2007 & $-0,18$ & $\mathrm{~s} 4$ \\
\hline 1986 & 0,19 & $\mathrm{~s} 4$ & 2008 & $-0,74$ & $\mathrm{~s} 4$ \\
\hline 1987 & 0,96 & $\mathrm{~s} 4$ & 2009 & 1,89 & $\mathrm{~s} 2$ \\
\hline 1988 & 1,61 & $\mathrm{~s} 2$ & 2010 & 0,60 & $\mathrm{~s} 4$ \\
\hline 1989 & $-0,15$ & $\mathrm{~s} 4$ & 2011 & 0,31 & $\mathrm{~s} 4$ \\
\hline 1990 & $-1,04$ & $\mathrm{~s} 5$ & 2012 & 2,44 & $\mathrm{~s} 1$ \\
\hline 1991 & 0,95 & $\mathrm{~s} 4$ & 2013 & $-0,51$ & $\mathrm{~s} 4$ \\
\hline
\end{tabular}

P transition probabilities matrix of Markov chains model is produced with the help of table 2 as follows. 


$\mathrm{P}=\quad \begin{array}{llllllll} & \mathrm{S}_{1} & \mathrm{~S}_{2} & \mathrm{~S}_{3} & \mathrm{~S}_{4} & \mathrm{~S}_{5} & \mathrm{~S}_{6} & \mathrm{~S}_{7} \\ \mathrm{~S}_{1} & 0 & 0 & 0 & 1,000 & 0 & 0 & 0 \\ \mathrm{~S}_{2} & 0 & 0 & 0 & 1,000 & 0 & 0 & 0 \\ \mathrm{~S}_{3} & 0 & 0 & 0 & 0 & 0 & 0 & 0 \\ \mathrm{~S}_{4} & 0,094 & 0,063 & 0 & 0,719 & 0,094 & 0,032 & 0 \\ \mathrm{~S}_{5} & 0 & 0 & 0 & 0,600 & 0,400 & 0 & 0 \\ \mathrm{~S}_{6} & 0 & 0 & 0 & 1,000 & 0 & 0 & 0 \\ \mathrm{~S}_{7} & 0 & 0 & 0 & 0 & 0 & 0 & 0\end{array}$

In the 44 years period, the initial probability vector of each class showing the possibility of occurrence of each $\mathrm{Sj}$ state;

$$
\begin{array}{cccccccc}
\mathrm{V}^{0}= & \mathrm{S}_{1} & \mathrm{~S}_{2} & \mathrm{~S}_{3} & \mathrm{~S}_{4} & \mathrm{~S}_{5} & \mathrm{~S}_{6} & \mathrm{~S}_{7} \\
0,068 & 0,045 & 0,000 & 0,750 & 0,114 & 0,023 & 0,000
\end{array}
$$

is as above.

After determining transition probability matrix and initial vector, with the aim of testing model, precipitation probability vector of 2014 is obtained as follows.

$$
\begin{array}{cccccccc}
\mathrm{V}^{2014}= & \mathrm{S}_{1} & \mathrm{~S}_{2} & \mathrm{~S}_{3} & \mathrm{~S}_{4} & \mathrm{~S}_{5} & \mathrm{~S}_{6} & \mathrm{~S}_{7} \\
0,070 & 0,047 & 0,000 & 0,744 & 0,116 & 0,023 & 0,000
\end{array}
$$

When analysing the precipitation probability vector of 2014 ; near normal state has the highest probability of occurrence with about $75 \%$ while, moderately humid and extremely dry states symbolised with $S_{3}$ and $S_{7}$ respectively have the lowest probability. Probability of occurrences of "extremely humid", "very humid", "moderately dry" "and extremely dry " states are $7 \%, 5 \%, 12 \%$ and $2 \%$ respectively. It is seen that total annual precipitation amount is $628,3 \mathrm{~mm}$, when looking the observed value for Kahramanmaras in 2014. That value falls within "near normal state" symbolised with $\mathrm{S}_{4}$ in SPI system. When investigating model results, it is seen that "near normal state" has the highest probability of occurrence.

Following the testing phase, probability vectors are found with the help of model for 2015, 2016, 2017, 2018, 2019 and 2020 years ; 


\begin{tabular}{|c|c|c|c|c|c|c|c|}
\hline & $\mathrm{S}_{1}$ & $\mathrm{~S}_{2}$ & $\mathrm{~S}_{3}$ & $\mathrm{~S}_{4}$ & $\mathrm{~S}_{5}$ & $\mathrm{~S}_{6}$ & $\mathrm{~S}_{7}$ \\
\hline $\mathrm{V}^{2015}=$ & 0,070 & 0,046 & 0,000 & 0,745 & 0,116 & 0,023 & 0,000 \\
\hline \multirow[t]{2}{*}{$V^{2016}=$} & $\mathrm{S}_{1}$ & $\mathrm{~S}_{2}$ & $\mathrm{~S}_{3}$ & $\mathrm{~S}_{4}$ & $\mathrm{~S}_{5}$ & $\mathrm{~S}_{6}$ & $\mathrm{~S}_{7}$ \\
\hline & 0,070 & 0,047 & 0,000 & 0,744 & 0,116 & 0,023 & 0,000 \\
\hline \multirow{3}{*}{$\mathrm{V}^{2017}=$} & $\mathrm{S}_{1}$ & $\mathrm{~S}_{2}$ & $\mathrm{~S}_{3}$ & $\mathrm{~S}_{4}$ & $\mathrm{~S}_{5}$ & $\mathrm{~S}_{6}$ & $\mathrm{~S}_{7}$ \\
\hline & 0,070 & 0,047 & 0,000 & 0,744 & 0,116 & 0,023 & 0,000 \\
\hline & $\mathrm{S}_{1}$ & $\mathrm{~S}_{2}$ & $\mathrm{~S}_{3}$ & $\mathrm{~S}_{4}$ & $\mathrm{~S}_{5}$ & $\mathrm{~S}_{6}$ & $\mathrm{~S}_{7}$ \\
\hline \multirow[t]{2}{*}{$V^{2018}=$} & 0,070 & 0,047 & 0,000 & 0,744 & 0,116 & 0,023 & 0,000 \\
\hline & $\mathrm{S}_{1}$ & $\mathrm{~S}_{2}$ & $\mathrm{~S}_{3}$ & $\mathrm{~S}_{4}$ & $\mathrm{~S}_{5}$ & $\mathrm{~S}_{6}$ & $\mathrm{~S}_{7}$ \\
\hline \multirow[t]{2}{*}{$\mathrm{V}^{2019}=$} & 0,070 & 0,047 & 0,000 & 0,744 & 0,116 & 0,023 & 0,000 \\
\hline & $\mathrm{S}_{1}$ & $\mathrm{~S}_{2}$ & $\mathrm{~S}_{3}$ & $\mathrm{~S}_{4}$ & $\mathrm{~S}_{5}$ & $\mathrm{~S}_{6}$ & $S_{7}$ \\
\hline $\mathrm{V}^{2020}=$ & 0,070 & 0,047 & 0,000 & 0,744 & 0,116 & 0,023 & 0,000 \\
\hline
\end{tabular}

is as above.

When examining results obtained, significant changes have not been seen by the years. For this reason, the obtained results can be stated a single probably vector. Ozgurel, \& Kilic (2003) also collected vectors belonging to 2003, 2004 and 2005 years under a single vector. Because, vector values were too close to each other. Following vector $\mathrm{V}^{\mathrm{G}}$ shows general probably of 2015, 2016, 2017, 2018, 2019 and 2020 years.

$$
\mathrm{V}^{\mathrm{G}}=\quad \begin{array}{ccccccc}
\mathrm{S}_{1} & \mathrm{~S}_{2} & \mathrm{~S}_{3} & \mathrm{~S}_{4} & \mathrm{~S}_{5} & \mathrm{~S}_{6} & \mathrm{~S}_{7} \\
0,070 & 0,050 & 0,000 & 0,740 & 0,120 & 0,020 & 0,000
\end{array}
$$

According to these results, possible precipitation amounts of 2015, 2016, 2017, 2018, 2019 and 2020 years are expected to be $1079 \mathrm{~mm}$ and above with $7 \%$ probably, 990-1078 mm with $5 \%, 545-900 \mathrm{~mm}$ with $74 \%, 456-544 \mathrm{~mm}$ with $12 \%$ and 367-455 mm with $2 \%$ respectively. However, precipitation amounts are not expected to vary between 901-989 mm and under $366 \mathrm{~mm}$ in Kahramanmaras. Generally, "near normal state" is dominant according to SPI system in Kahramanmaras and it is expected that precipitation amount vary between 545 and $900 \mathrm{~mm}$. Karabulut, \& Cosun (2009) reported that annual average precipitation amount and coefficient of variation were $709,8 \mathrm{~mm}$ and $23,26 \%$ (medium) respectively in Kahramanmaras according to 1975-2005 data. They also indicated that statically insignificant fluctuation was observed in precipitation amounts. This situation contributes that near normal state is dominant in the study area.

\section{CONCLUSION}

In this study in which are determined annual precipitation probabilities for Kahramanmaras city, Markov chain model is established and results are evaluated. Observed total annual 
precipitation amount of year 2014 has been compared with values obtained with model on the purpose of testing model accuracy. Precipitation range whose probability of occurrence is the highest according to model result for 2014 has ranged from $545 \mathrm{~mm}$ to $900 \mathrm{~mm}$ with $74 \%$. Observed value for 2014 is $628,3 \mathrm{~mm}$ in Kahramanmaras and this value falls within class whose probability of occurrence is the highest.

When model is run for 2015, 2016, 2017, 2018, 2019 and 2020, almost the same results have been reached. According to these results, total annual precipitation amount is expected to vary between 545 and $900 \mathrm{~mm}$ with $74 \%$ probably along $2015-2020$ period in Kahramanmaras city.

\section{REFERENCES}

Akyurt İ. Z. (2011). Ülke Derecelendirme Sisteminin Markov Zinciri İle Analizi. Yönetim Dergisi, y1l: 22, say1: 69, İstanbul Üniversitesi.

Ameur L. S., \& Haddad B. (2007). "Analysis of precipitation data by approach Markovienne" Larhyss journal, no. 6, pp. 7-20.

Arnaud M. R. (1985). "Contribution to the study stochastic Markovienne of precipitation in the Adour-Garonne basin"; thesis of Phd, Toulouse, (France).

Austin L., Burns M., \& James R. (1985). Management Science: An Aid for Managerial Decision Making. Macmillan Publishing Company: New York.

Barkotulla M. A. B. (2010). Stochastic Generation of the Occurrence and Amount of Daily Rainfall. Pak.j.stat.oper.res. Vol.VI No.1, pp61-73.

Cosun F., \& Karabulut M. (2009). Kahramanmaraş' ta Ortalama, Minimum ve Maksimum Sicaklıkların Trend Analizi. Türk Coğrafya Dergisi Sayı 53: 41-50, İstanbul.

Dash P. R. (2012). A Markov Chain Modelling Of Daily Precipitation Occurrences Of Odisha. International Journal of Advanced Computer and Mathematical Sciences, Vol 3, Issue 4, pp 482-486.

DMİ, (2010). Devlet Meteoroloji İşleri Gn. Md., K.Maraş Meteoroloji İl Müdürlüğü, K.Maraş Meteoroloji İstasyonu Verileri, 1975-2010. Kahramanmaraş.

IPCC, (2014). Climate Change 2014: Synthesis Report. Contribution of Working Groups I, II and III to the Fifth Assessment Report of the Intergovernmental Panel on Climate Change [Core Writing Team, R.K. Pachauri and L.A. Meyer (eds.)]. IPCC, Geneva, Switzerland, $151 \mathrm{pp}$.

Karabulut, M., \& Cosun, F. (2009). "Kahramanmaraş İlinde Yağışların Trend Analizi." Coğrafi Bilimler Dergisi, 7 (1): 65-83.

Kocak K., \& Sen Z. (1998). Kurak ve yağışıı gün oluşumlarının Markov zinciri yaklaşımı ile uygulamalı incelenmesi. Tr. J. of Engineering and Environmental Science, 22 , 479 487.

Korkmaz H. (2001). K.MARAŞ Havzası'nın Jeomorfolojisi. Marmara Üniversitesi Sosyal Bilimler Enstitüsü Coğrafya Eğitimi Anabilim Dalı Doktora Tezi. İstanbul.

Kottegoda N. T, Natale L., \& Raiteri E. (2004). Some considerations of periodicity and persistence in Daily rainfalls, J. Hydrol. 296:23-37.

Lazaro R., Rodrigo F. S., Gutierrez L., \& Puigdefafregas J. (2001). Analysis of a 30-year rainfall record (1967-1997) in semi-arid SE Spain for implications on vegetation, J. Arid Environ., 48, 373 - 395. 
McKee T. B., Doesken N. J., \& Kleist J. (1993). The Relationship of Drought Frequency and Duration to Time Scales, Preprints, 8th Conference on Applied Climatology, 17-22 January, Anaheim, CA, pp.179-184.

N'guessan B1 V. H., Saley M. B., Pop S., Terebech R., Be B., Djagoua E. V., Kouamé F., Borda M., \& Affian K. (2014). Markovian approach for analysis and prediction of monthly precipitation field in the department of Sinfra ( Central-west of Côte d'Ivoire). International Journal of Engineering Research and General Science, Volume 2, Issue 1, January.

Oguzturk G., \& Yıldız O. (2014). Kırıkkale ilinde farklı zaman periyotları için kuraklık analizi. International Journal of Engineering Research and Development, Vol.6, No.2.

Ozgurel M., \& Kılıc M. (2003). İzmir İçin Geleceğe Yönelik Yağış Olasılıklarının Markov Zinciri Modeliyle Belirlenmesi. Ege Üniv. Ziraat Fak. Derg., 40(3):105-112.

Selvi S. T., \& Selvaraj R. S. (2011). Stochastic Modelling of Annual Rainfall at Tamil Nadu. Universal Journal of Environmental Research and Technology, Volume 1, Issue 4: 566570.

Srikanthan R., \& Mc Monan T. A. (1984). Stochastic generation of rain-fall and evaporation data. AWRC technical paper No: 84, 301.

Taylor H. M., \& Karlin S. (1984). An Introduction To Stochastic Modeling, Orlando, Florida, Academic Press, Inc.

Turkes M., (2011), Akhisar ve Manisa Yörelerinin Yağıș ve Kuraklık İndisi Dizilerindeki Değişimlerin Hidroklimatolojik ve Zaman Dizisi Çözümlemesi ve Sonuçların Çölleşme Açısından Coğrafi Bireşimi. Coğrafi Bilimler Dergisi CBD 9 (1), 79-99.

Turkes M. (1999). Vulnerability of Turkey to desertification with respect to precipitation and aridity conditions. Turkish Journal of Engineering and Environmental Sciences 23, 363-380.

Winston, W. L. (2004). Operations Research-Applications and Algorithms. Brooks/Cole, Fourth Ed: USA.

Yusuf A. U., Adamu L., \& Abdullahi M. (2014). Markov chain model and its application to annual rainfall distribution for crop production. American Journal of Theoretical and Applied Statistics, 3(2): 39-43.

Zamani A. M. R, Monadi M., \& Zarei H. (2013). Usıng A First Order Markov Chain Model And Spı Index To Forecastıng, Monitorıng And Zonıng Of Meteorological Drought Case Study: Chahar Mahal And Bakhtiar1 Province, Iran. Journal of Environmental Research And Development, Vol. 8, No. 2. 